\title{
Renewing Shadow Puppet Musics Created by Sukron Suwondo
}

\author{
Sukesi \\ Faculty of Performing Art, Indonesia Institute of the Arts, Surakarta, Indonesia
}

\begin{abstract}
"Renewing Shadow Puppet Musics Created by Sukron Suwondo" was a research to accelerate in achieving the position of chief lecturer funded by DIPA ISI Surakarta. This research used qualitative descriptive method by using data collection techniques through literature review, interview, recording, and transcription. This research tried to uncover two problem formulations, namely (1) the background of creating the Sukron Suwondo musical composition, (2) the relevance of Sukron Suwondo's work to contemporary performance. To answer these two problem formulations, interviews were also conducted with four dalang (traditional puppeteers) who often used Sukron Suwondo's works, including Seno Nugroho, Anom Dwijo Kangko, Sigid Aryanto, and Cahyo Kuntadi. The results of this study indicated that there were a number of factors underlying the innovations carried out by Sukron Suwondo, as well as other things that made the work of Sukron Suwondo relevant to the needs of today's pakeliran (Javanese traditional shadow puppet show).
\end{abstract}

Keywords: Javanese music, shadow puppet, Sukron Suwondo

DOI: $10.7176 / \mathrm{ADS} / 79-08$

Publication date: December $31^{\text {st }} 2019$

\section{Introduction}

Karawitan (Javanese music) was one element that could not be separated from shadow puppet shows. The position of a group of gamelan music was very important, because it served as a supporter that determined the atmosphere when the scenes in the shadow puppet show were built (Sunardi, 2013: 66). While the classification of the use of gendhing (Javanese song) as supporters of shadow puppet shows, hereinafter commonly referred to as Javanese music for shadow puppet show. Murtiyoso clearly defined that Javanese music for shadow puppet show were all vocal and instrumental sounds that were used to bring about the dramatization in shadow puppet shows (Murtiyoso, 1980: 9)

The function of Javanese music for shadow puppet show aside from being a mood builder in a whole night shadow puppet show was as a time marker that framed the structure of the play in note area. The note area that framed the structure of the play was divided into three pathets, namely at 09.00-12.00 in the pathet nem area, 12.00-03.00 in the pathet sanga area, while at 03.00- finished in the pathet manyura area (Soetarno, 2007: 59) .

Since the establishment of PADASUKA, an education studio founded by the Surakarta Palace, the use of traditional song in shadow puppet show was determined according to the scene and the position setting where the scene was located. For example, Ktw Gendhing Kabor, $k t 2 k r$, was used specifically in the jejer scene in Hastina Kingdom. Babak unjal (guest arrival) Ldr Peksi Kuwung, paseban njawi using Gendhing Semukirang, and other music. But today, the development of shadow puppet shows that kept up with the mindset of modern society, also affected the change of shadow puppet performances format, including in the use of Javanese music for shadow puppet show.

Post-independence era began with the emergence of Ki Narto Sabdo. At that time the use of Javanese traditional song began to experience renewal. This was driven by the creativity possessed by Narto Sabdo in making and creating song. These changes in the form of song-using that was adapted to the scene in progress, for example, the use of Ktw Margiyuh Sl. Manyura in Kunthi's pregnancy scene. The verse and tone were adjusted to the circumstances and situation of Kunthi at that time.

Today, the increasingly widespread use of Javanese music songs made the needs of these songs increasingly diverse. This required a puppeteer to be more creative in combining a whole shadow puppet performance. The situation eventually led to the presence of creative artists including Sukron Suwondo, a puppeteer from Blitar, East Java. Sukron Suwondo's work was currently widely used by young puppeteers who had influence in the shadow puppet realm. The puppeteers were Ki Cahyo Kuntadi, Ki Anom Dwijo Kangko, Ki Sigit Ariyanto, and Ki Seno Nugroho from Yogyakarta. The four puppeteers were informants for the research on Sukron Suwondo songs, with the reason that the four puppeteers were figures who became the standard for today's development of national puppetry. The above raised questions in my mind. 1. What was the process of creating songs of Sukron Suwondo in Javanese music for shadow puppet show? 2. How was the relevance of shadow puppet shows songs made by Sukron Suwondo, related to the needs of present-day shadow puppet show?

\section{Literature Review}

Research on the work of Sukron Suwondo was a study conducted to see a work in an aesthetic perspective, its connection with its use in shadow pullet shows. For this reason, a literature review was needed to see the position 
and authenticity of the research. Some reading materials that I had encountered included:

The thesis, entitled "Pertunjukan Wayang Kulit Sukron Suwondo" (Harbono, 2004), was a thesis used as a prerequisite for obtaining a Master of Arts degree at the Indonesian Institute of the Arts, Surakarta, majoring in Art Studies. This thesis wrote more works by Sukron Suwondo in the field of puppetry, and their position in the eyes of Sukron Suwondo fans. Creations that were musical compositions for shadow puppet show were not much discussed in detail, both those used by Sukron Suwondo, and those used by other puppeteers as an alternative to the musical composition of shadow puppet show today. But this thesis was very useful especially in getting information about Sukron Suwondo's work in the field of puppetry.

"Studi Kasus Pakeliran Wayang Kulit Purwa Sukron Suwondo beserta Tindak Tuturnya (Kajian Sosio Pragmatik)" (Harbono, 2014). The dissertation was structured to meet the requirements in getting a doctoral degree at Universitas Negeri Surakarta (Surakarta State University). This dissertation revealed the characteristics of Sukron Suwondo puppetry by taking a few examples of the play namely, Kyai Udan Mas, Semar Ruwat, and Dasamuka Lahir. This research examined more types of tindak tutur and their functions in society. The results of this study were the discovery of three things from the shadow puppet shows of Sukron Suwondo, which had changed shape, the second was the characteristic of Sukron Suwondo that distinguished him from other puppeteers, and the third was the finding of the dominance of tindak tutur in the example of the shadow puppet show. But a study of the aesthetic value contained in Sukron Suwondo's shadow puppet show songs was not found.

A book titled Pembaharuan Wayang Untuk Penonton Terkini. (Kitsie Anne Emerson, 2007). This book examined the way to staging shadow puppets throughout the night from the idea to the presentation. From this book, I got a lot of information about the periodization of the shadow puppet development from the palace to formal educational institutions, which were commonly referred to as conventional shadow puppet and new creation-shadow puppet. Conventional shadow puppet was the term for classic shadow puppet that had been standardized by the Keraton (the Palace), while new creation shadow puppet was a new form of shadow puppet which was the idea of Gendhon Humardani from ASKI (currently known as ISI). Because it referred to the development of new creation-shadow puppet, the research object of this book was Purbo Asmoro's shadow puppets, supported by ISI Surakarta-style traditional music. In this book, I did not find any information about the shadow puppets created by Sukron Suwondo, which was currently more widely used by some young national puppeteers.

After examining a number of writings on shadow puppet created by Sukron Suwondo and some information regarding the renewal of shadow puppet shows, it could be understood that no similarity had yet been found, either in the form of formal objects or material objects. For this reason, it could be ascertained that this research was original, and its authenticity could be accounted for.

\section{Methods}

This was a qualitative descriptive research. Qualitative descriptive research was a way of examining the class of events in the present by producing data in the present in the form of written or oral words from people and observed behavior. In addition, qualitative descriptive research had characteristics including: scientific background, relying on humans as research objects, utilizing qualitative data, using inductive analysis, directing research objectives to finding basic theories that were descriptive, prioritizing processes rather than results, limiting studies to the focus of a particular problem, the research design is temporary, and the results of the research were acceptable to all parties.

In data collection there were several methods used, but not all methods could be applied in every type of research. Therefore it was very important to consider appropriate techniques in data collection. The data collection methods used in this study was literature study, observation, interviews, data analysis, and transcription.

Literature study was a way that I used by collecting various books and information related to scientific works that made Sukron Suwondo as an object of research, as well as information about renewal in the shadow puppets realm, especially those relating to songs as accompaniment music. This was done to see the position of research and the originality of formal objects and material objects.

Observation was a data collection technique by making observations directly to the location and carrying out systematic recording of the observed phenomena. The object that I observed was a performance performed by four puppeteers, for example of the use of songs created by Sukron Suwondo in a shadow puppet show. Observations made by watching audio-visual sources many times so that I got clear and accurate information.

Interviews were conducted to reassure data that already existed. Interviews were really needed to be done to get more valid data about the information needed. Informants to be interviewed included Ki Sukron Suwondo, Ki Anom Dwijo Kangko, Ki Cahyo Kuntadi, Ki Sigit Aryanto, and Ki Seno Nugroho.

Transcription was the process of recording objects. This was done so that I would be easier to make further observations regarding the course of the performance. In addition, I rewrote what was presented in the recording to be presented in the data analysis.

Data analysis was the last action taken after data collection. The data that had been collected was then re- 
selected, classified according to the problem to be examined. After that, a comparison was made of the data obtained from observations, interviews, literature reviews, and transcriptions. Then all data was presented systematically so that it was easy to understand, and illustrated the problems of the research. After that a conclusion was drawn from all data that had been obtained and compiled.

\section{The work process of Sukron Suwondo}

Sukron Suwondo was an artist born in Blitar 64 years ago. He lived in Karangjati Hamlet, Purworejo Village, Sanan Kulon District, Blitar Regency, East Java. His father was Sukemi, a famous puppeteer, especially in Blitar Regency. Since childhood, Suwondo learned as a puppeteer and performed for the first time when he was in grade 6 in elementary school. The thing most liked by Sukron Suwondo was puppet literature, as well as sabet wayang. Aside from being a puppeteer, Sukron Suwondo was known to be active in creating various shadow puppet accompaniment musics that provided a new atmosphere for the conventional shadow puppet world in general. These novelties included the use of songs as a substitute for sulukan, as well as songs that he created based on what was actually happening.

Suwondo's sensitivity to new things, as well as his enthusiasm to always displayed novelty, both in terms of sanggit and song was caused by boredom about anything monotonous. In addition, Suwondo claimed that another thing that made him motivated to change the existing song was to cover up the shortcomings of his voice which he said were tight, or short (his breathing) (interview September 30. 2019).

In a puppet show, for example, it was very common that the Suwondo performance started with Srepeg Mataraman as an accompaniment to a flash back scene, and continued with Ladran Semarangan in jejer scene. This was something that had never been used in conventional puppet show in general. Or suddenly to break the ice, Suwondo replaced the sulur pathet lindur, with a ketawang lindur which he composed himself as a substitute for the atmosphere of the pathet nem scene to the pathet sanga. These packages eventually got a place in the puppet-loving community, because the show was considered to be enjoyable, and felt to flow smoothly from one scene to another, did not tend to linger, and seemed fresh.

Internal factors in Sukron Suwondo became one of the important factors for the creation of his works and ideas towards the need for contemporary musical in shadow puppet show. Besides that, another factor that made Suwondo creativity developed was his participation and enthusiasm for traditional theatre, namely kethoprak. He used to stage with the kethoprak group Siswa Budaya from Tulungagung, East Java, both as a player and a creative team. The position required to always have bright ideas for the Siswa Budaya ketoprak show, so as not to be quickly abandoned by the audience.

Suwondo's musical compositions eventually became relevant for the needs of today's puppet shows, as evidenced by the large number of young puppeteers who were now playing his music in their performances. The puppeteers were included Seno Nugroho, Anom Dwijo Kangko, Cahyo Kuntadi and Sigid Aryanto. These four puppeteers were used as examples, because of their reputation and existence on the puppet stage today. They had the most viewers compared to other young puppeteers who were on the rise, as evidenced by the large number of performances they did every month. One of the musical performances by Sukron Suwondo that could be displayed was Ketawang Lindur Lrs Slendro Pathet Sanga as followed:

Ketawang Pathet Lindur Lrs Slendro Pathet Sanga

$\ldots \ldots n 6 \quad 3565321 g 2$

..21 653 n5 $232121 \mathrm{ygt}$

$11 \ldots$ ty2n1 $1121 \quad 156 \mathrm{~g} 1$

(Sukron Suwondo,2014

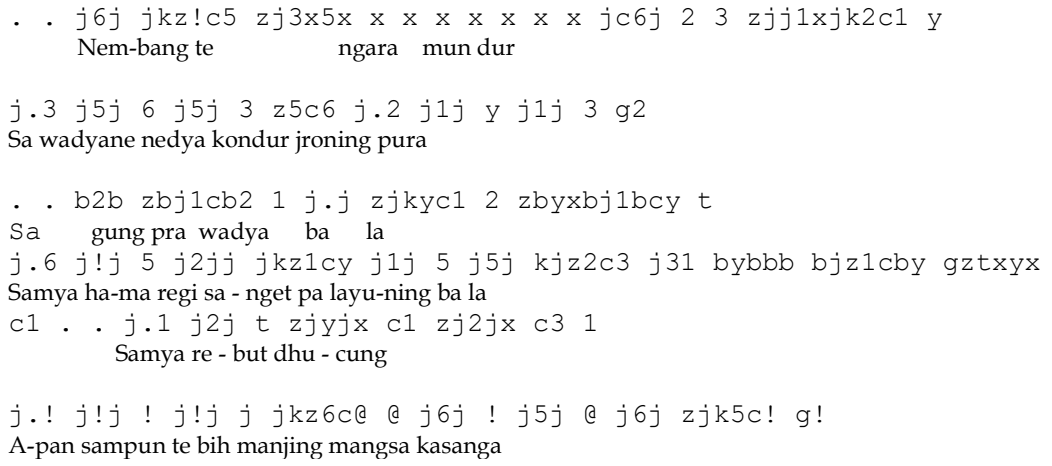

If you looked at that ketawang lindur when seen from the pathet conception in Javanese traditional music, there were two pathets that appeared together, namely the pathet nem and sanga. At the beginning of lindur was 
the pathet nem, until the phrase "Wus ngancik mangsa kasanga" sense of song turned into pathet sanga, with the dominance of ji cilik (nutur ji) in its presentation. These things were considered by Sukron Suwondo to be the needs of today's general audience. This meant that the puppeteer did not have to make various long-winded suluk, but the suluk of puppet show had become a series of puppet show songs, which could be used to accompany certain scenes according to the atmosphere to be reached.

Another work that was often used in puppet shows was, Srepeg Kedhu Slendro nem, which was created by Sukron Suwondo to accompany the scene after budhalan. In traditional puppet shows, after budhalan was usually marked with pathet kedhu to go to the next scene. But for Sukron Suwondo, pathet kedhu was replaced by thissSrepeg kedhu, whose poems and songs were also taken from the pathet kedhu's melodic path. SREPEG KEDHU Lrs Pelog Pathet Nem

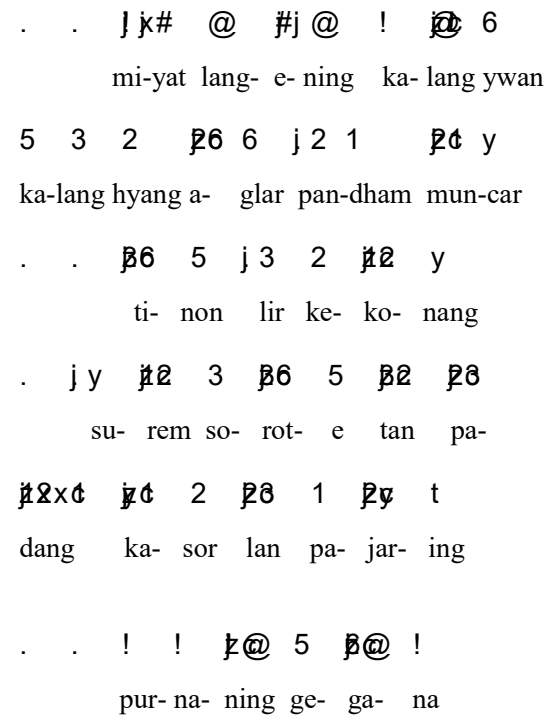

Sukron Suwondo's work was not only used as an alternative to replace existing habits, but also functioned as social criticism. The social criticism was found in each poem contained in the work, as found in the poem Srepeg Njlewar Ngawur Slendro nem as followed:

\section{NJLEWAR NGAWUR Lrs Pelog pathet Nem}

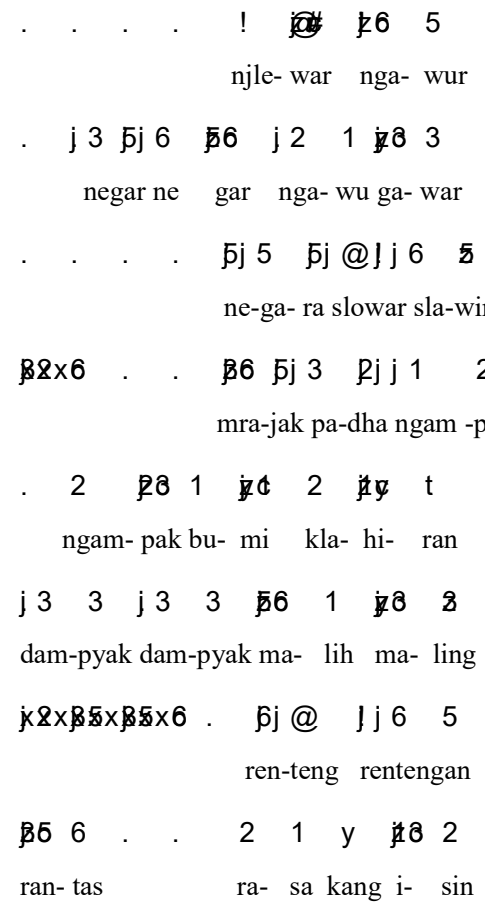

(Not following the rules, the country is inconsequential, A country that doesn't heed the national order, Humans 
are destroying the homeland, Being a thief together, Together, throw away the shame)

\section{Sukron Suwondo According to the Puppeteers a. Seno Nugroho}

Seno Nugroho was a puppeteer born in Yogyakarta, on August 23, 1972. He took formal puppetry from the Sekolah Menengah Karawitan Indonesia (SMKI), Yogyakarta, graduated from the SMKI Puppet Mastery Program in 1991. Before entering formal school, his knowledge of puppetry was acquired by self-taught, just by looking at Ki Suparman, his father's shows. His admiration for puppetry increased, when he first saw the performance of Manteb Soedarsono at Sasana Hinggil Dwi Abad, Palace of Yogyakarta. Because of his love for Manteb, until now Seno Nugroho had been able to bring two styles of shadow puppet shows, the Yogyakarta style and the Solo style.

Seno Nugroho claimed to often use Javanese music for shadow puppet show created by Sukron Suwondo, he claimed that Sukron Suwondo's works had a light language style and were relevant for the needs of today's shadow puppet shows. Seno claimed to be impressed with the figure of Sukron Suwondo, in fact there were many things from the Sukron Suwondo puppet show that inspired Seno Nugroho's performance. In terms of accompaniment music, Seno claimed to have used Sukron's works for a long time, in addition because no one had used them, it was also because Sukron Suwondo's work seemed simple, and light to listen to (interview 1 October 2019).

\section{b. Anom Dwijo Kangko}

Anom Dwijo Kangko was one of the puppeteers who did sensational things at the first World Puppet Day event at ISI Surakarta in 2015. He was born in Blitar, on October 9, 1978. Since he first appeared, Dwijo Kangko was known for his expertise in demonstrating sabet. In addition to the attractive puppet movement, after Enthus Susmono passed away, Dwijo Kangko was the puppeteer who was known to often present sensational things in each of his performances,

These sensational actions included combining elements of modern theater, such as when Dwijo Kangko performed at the first World Puppet Day event at ISI Surakarta in 2015. In the Gondomono Tundung story which revolved around Haryo Suman's slander of Gondomono, Dwijo Kangko expressed Gondomono's anger with total emotions, including at the end, as if he himself were the Gondomono, he stood and beat Suman. The puppeteer who initially played the puppet, suddenly turned into the puppet itself. In an interview conducted on July 11, 2019, Kangko admitted that he brought it because he was carried away by the emotions he brought himself. In addition, he deliberately tried to explore, because in addition to his ability in acting, he was also motivated by his experience of seeing modern theater performances (Interview, Dwijo Kangko: July 11, 2019).

Kangko, who was also the second child of Sukron Suwondo, admitted that he liked his father's work, because the compositions made by his father were really new, and not many people used it. Therefore to overcome the boredom of the audience towards something that already existed, Kangko tried to present Sukron's work as an alternative as the new shadow puppet show music (interview, August 30, 2019).

\section{c. Sigid Aryanto}

Sigid Aryanto was born in Blora, in June 1979. He currently lived in Leteh, Rembang, Central Java. He completed his undergraduate education at the Indonesia Institute of the Arts Surakarta Puppetry Department, as the best graduate in 2003. As a lecturer, Sigid Aryanto adhered strictly to the rules of puppetry. He mastered all elements of puppetry well, ranging from sabet, catur, musical accompaniment, and play. His debut as a puppeteer began when Sigid won the National Puppet Festival in 2008.

Despite mastering all elements of puppetry, the most striking thing about Sigid's expertise was his ability to process plays. He had the ability to interpret sanggit since he was in the Puppetry Department. This was evidenced by some of his manuscripts used by the campus for staging long screen puppets. These works included "Parikesit" at Teater Lingkar Semarang (2002), "" Hastabrata Kawedhar Pakeliran Padat at Semarang State University (UNES) Anniversary (2005), and Indonesian Language Puppet (Sandosa) "Karna Tandhing" in the Netherlands and Italy (2003).

Sigid Aryanto was a puppet master whose experience in adopting Sukron Suwondo works in shadow puppet show was longer than in the other three puppeteers. Since the 2000s Sigid had used a lot of Sukron's works. Even today, Sigid was still memorized by heart, all of Sukron Suwondo's works. Sigid's admiration was not only for the song created by Sukron Suwondo, but also for the work of Sukron Suwondo puppetry. He admitted that when he was in school, every time he had a semester break, Sigid always took the time to go home to Blitar, in the Sukron Suwondo residence, to learn a lot from him. (interview, July 29, 2019)

\section{d. Cahyo Kuntadi}

Cahyo Kuntadi was a puppeteer born in Blitar. He was the third child of Sukron Suwondo. His debut as a puppeteer began when he was a child. When Cahyo was in Middle School, he had often appeared as a dalang pepucuk (puppeteer who opened a show). He was also active in activities like young puppeteers festivals. Cahyo was known as a puppeteer with expertise in sanggit, since his work Abhimanyu Ranjab became the best performance in the 2008 National Puppet Festival. In addition, he also won the best actor title by bringing the play Gathutkaca Gugur at the 2013 World Puppet Carnival. Regarding music created by his father, Cahyo considered that so far the 
accompaniment music for shadow puppet shows created by composers seemed to have the same nuance, so that if they were juxtaposed there were no significant differences. Sometimes even composers today ignore the sense of shadow puppet that should be present in the music that accompanying shadow puppet performances. The sense of shadow puppet in question is feel that should be achieved and existed only in a shadow puppets show, while at this time many were accompanied by a sense of dance drama.

Cahyo argued that only Sukron Suwondo's works had been able to represent the atmosphere of Shadow puppet. This was because Sukron Suwondo as the creator and composer of the work was a puppeteer who understood the contents of Shadow puppet shows. In addition, Sukron Suwondo had a lot of experience in the field of traditional theater. This was as seen in Ki Narta Sabda, a famous puppeteer. His experience also originated from the tobong tradition, also known as traditional theater performances.

\section{Conclusion}

Research on the renewing shadow puppet music created Sukron Suwondo finally came to the chapter of conclusion. Some things that could be taken from this research were the answers of the existing problem formulations. Answering the first problem formulation, related to the background of the creation of Sukron Suwondo, that there were two factors, namely internal factors such as the encouragement of Sukron Suwondo himself, and external factors namely the encouragement from outside of Sukron Suwondo, among which were the characteristics of the audience and the people's appreciation towards the form new vocabulary of song which was considered lighter and more popular.

The second problem, namely the relevance of music by Sukron Suwondo, was answered through interviews with puppeteers who used Sukron Suwondo a lot. It could be concluded that the music created by Sukron Suwondo was considered as something new, which could lead to other things that had not existed before. Besides that, the music created by Sukron Suwondo was considered comfortable to build the atmosphere of the shadow puppet show because it was made by a dalang who understood the atmosphere of the scene in a shadow puppet show.

\section{References}

Anne Emerson, Kathryn, Pembaharuan Wayang Untuk Penonton Terkini Gaya Pakeliran Garap Semalam Sajian Dramatik Ki Purbo Asmoro 1989-2017. Surakarta: ISI Press 2018

Harbono. "Pertunjukan Wayang Kulit Sukron Suwondo". Tesis Pasca Sarjana Sekolah Tinggi Seni Indonesia Surakarta, 2004

Harbono. "Studi Kasus Pekliran Sukron Suwondo Beserta Tindak Tuturnya Kajian Sosio Pragmatis" . Desertasi Universitas Sebelas Maret Surakarta, 2014

Soetarno, Sunardi, Sudarsono. Estetika Pedalangan. Surakarta: CV Adji, 2007

Sunardi, Nuksma dan Mungguh Konsep Dasar Estetika Pertunjukan Wayang. Surakarta: ISI Press, 2013 